\title{
Reason, survival, progress in eighteenth century thought 1
}

\author{
J.J. Venter \\ Department of Philosophy \\ Potchefstroom University for CHE \\ POTCHEFSTROOM
}

\begin{abstract}
This article aims at an exposition of the coherence among the concepts of reason, survival and progress in eighteenth century thought (assuming that present-day, critical analyses of rationality, unlimited economic growth and the competition-generated pressures of life refer to concepts rooled in the eighteenth century). Eighteent century thought is exemplarized in the economic thought of Adam Smith and the social/political thought of Kant (with a few references to Hume's ideas on ant) in an attempt to show that the coherence among those concepts ought to be understood from the angle of the (then) impontant motive of conflict/competition. Conflict and competition were seen as mechanisms of progress and survival in competitive circumstances as a standard or sign of progress; rationality was directly connected with sunival.
\end{abstract}

\section{INTRODUCTION}

\subsection{Reason / survival / progress / eighteenth century}

This article is not primarily aimed at producing an argued 'proof' of some proposition, but is rather intended as a documented exposition of the coherence among (the cluster of) the concepts of reason, survival and progress in the eighteenth century. Such an exposition finds its motivation in present-day critical analyses of rationality, unlimited economic growth and technological expansion, and the competition-generated pressures of contemporary life. For the purposes of this article, it is assumed that contemporary Western culture has important roots in the eighteenth century, and that these concepts are part of those roots. (It does not fall within the scope of this article to analyse the historical links that connect today's pressure for success (pragmatism, profiteering and winning as life styles) to Darwinism and nineteenth century capitalism, and the latter again to those eighteenth century concepts; a few pointers at the end will have to do.)

1 The financial assistance of the Institutc for Rescarch Development of the HSRC is hereby gratefully acknowledged. Opinions expressed and conclusions drawn are those of the author and do nol necessarily reflect the vicws of the IRD or HSRC. 
The eighteenth century is the century of the Enlightenment as well as the beginnings of Idealism in the transcendental thought of Kant. All eighteenth century thinkers can of course not be discussed here; we shall rather exemplarize that century in analysing the thought of Adam Smith and Kant (with a few references to ideas of Hume - discussed in Venter, 1992? - and others). Adam Smith, one would expect, would - in a philosophical context tempt approach from the angle of 'moral sentiments'; I intend to disrupt such expectations and zoom in on Smith, the economist. And, for once, Kant's three Critiques may take backstage in favour of some shorter - and less known - treatises.

In the coherence among the mentioned concepts, the motive of conflict/competition played a very important role at the time - it functioned as mechanism of progress, and surviral against the odds of conflict/competition, as a sign or a standard of progress. Rationality can directly be related to survival (Hume; cf. Venter, 1992?:126), or transcend competition as an ideal (Adam Smith), or even be the factor causing the conflict (Kant).

The exposition is built upon different kinds of evidencing:

* To understand the conceptual coherence in historical context, a limited characterisation of the Enlightenment, as the dominating view of man and world in the eighteenth century, and the populariser of the belief in progress, is given in advance. This characterisation is used as an explanatory device in the discussion of the two authors. who, on their part. may serve as concrete illustrations of the characterisation. This procedure may appear as a hermeneutical circle, but the characterisation is not in itself solely dependent upon the present illustrative figures, but rather on a wide reading of the primary sources, which cannot be documented here.

* It is attempted to show that the motive of conflict/competition is not considered a good in itself. or the morally best way there is, but rather a necessary evil or the unavoidable use of a good of lower ranking order, which has to be eliminated by some mechanistic, Newtonian state of equilibrium (once the necessary advancement has been attained)

- The focal point of the exposition is the motive of conflict/ competition as a Western. cultural motive. The functioning of this cultural motive, however, can oniy be explained within the larger thought context of thinkers working in different intellectual spheres. In this case one has to take account of Adam Smith's views on ethics and (especially) the foundations of economics and Kant's ideas on history 
and politics. (Hume's method of judging the quality of a literary work on the basis of its survival against competition, as discussed in Venter (1992?), can of course also be noted in this context.) Only by tracing the motive in these different areas (thus giving the article a somewhat interdisciplinary flavour), can conflict/competition be presented with some ground as a cultural motive. The relevance of the latter is, of course, that it may (partially) explain twentieth century views on cultural motor forces (cf. Mussolini, 1935; Foucault,1986).

What could the sense of an exposition like this one be? It may serve as a disclosure of some of the invisible roots of our culture, specifically present-day obsessions with 'competition', and 'victory', and also help to explain some of the resistance against 'success', 'bigger and better', and 'self-interest' (cf. Heidegger, 1938; Horkheimer, 1978; Capra, 1984). From a critical point of view, it thus makes sense to close the article with a few remarks on rationality as self-interest, 'progress' with or without competition, and conflict/competition as the true (?) basis of society.

\subsection{The eighteenth century}

The link between the French Enlightenment and the French Revolution indicates that the Enlightenment must have been more than just another philosophical movement. For those who adhered to it, it was a life-view (i. e. it had become a directive vision for practical life). In fact, it might be maintained that the Enlightenment provided the first fundamentally new life-view after the decline of medieval Christianity had set in. Neither the classicism of the Renaissance, nor the scientism of Descartes c.s. exceeded the synthetic life-view of the Middle Ages, which allowed for a synthesis of Christian and Classical ideas. They were, rather, new accents within the old framework. The Enlightenment, however, constitutes a clear break with the synthetic life-view (by eliminating the last remnants of Christian doctrine from it).

Enlightenment, as Kant (1783:53) said, represented rational man's coming of age. It was, in fact, a form of rationalism which took as its focal point the spontaneous rationality (logicality) expressed in cultural practice (rather than limiting or reducing rationality to mathematically intuited truths based on innate or experiential primitive ideas).

The synthetic life-view was rejected in favour of the 'Classical': we see the very basic Christian idea of God's guidance (implying the dependence of man) replaced with the belief in the (inevitable) progress of mankind, combined with a new kind of classicism. 
Those who did find a place for God in the belief in progress, seem to have hidden him behind a pantheistically conceived 'nature', and conceived of man as continuously unfettering himself from the bonds with which he had been bound by nature. Enlightenment man is comforted by the firm belief that his children will have it better, and that this process will not be reversed (those with a more scientistic leaning, like the Marquis of Condorcet, would say: cannot be reversed). Representations of the Enlightenment recognise that their contemporary situation was far from ideal, but believe that, almost inevitably, progress would continue - such is the 'guidance' of nature. Prerequisite to such a view was a conception of 'nature as teleological, man-centred, yet transcending man. This implied a (not always explicitly recognised) dialectical view on the relationship between nature and culture: both romanticising nature and accepting the inevitability of progress.

The Enlightenment accommodates a variety of views on 'nature'. The most common characteristic of these views on nature is their teleological man-centredness: it refers to what man, seen from the perspective of his origin, essentially is, or should be, or is intended to become (or all of these together). Within this anthropocentricism there is a wide variety of views: the original, pre-social man (Rousseau); the free, teleologically guided development of the original, rural, farming hawker (Adam Smith); the intellectually refined courtier (Hume). (To these may be added Kant's animalistic, instinctual, pre-rational man.)

These thinkers were struggling with 'evil' as a counter-example for progress. The anthropocentric conception of nature implied that man was uplifting himself, yet it was factually true that man was suffering at the hands of man (the Jacobins!). As is often the case in providential theologies, so also in this 'naturalist' teleology: 'evil' is incorporated into the intentions of the dominant 'good'. Competition, inequality, lack of freedom, conflict, are recognised as 'evils', but are also conceived of as essential components in the progress to a social order in which these evils will be absent/neutralised. In the interim period absolute state power has to guarantee my freedom (Rousseau); or: I expect my bread and beef from the selfishness of the baker and the butcher (Adam Smith); or: cultural progress is guaranteed by the continuous preparation for war (Kant).

No view which bases human progress on conflict, competition, selfinterest, striving for honour, power, etc., can provide much doctrinal space for the opposite ideas, like 'loving your neighbour' and 'loving your enemy'. Thus Christianity - if seriously practised - would be an obstacle to progress, and Rousseau would not allow Christianity to be the civil religion. 
The Enlightenment turned away from Christianity to Classical culture for its inspiration. Classicism is already present in the Renaissance, and we could of course ask what the relationship between these two classicisms might be. As in the Renaissance, so in the Enlightenment we find the somewhat Stoic gushing about nature, the republicanist ideal, the romanistic warrior mentality, and the appreciation of especially the literary arts. Enlightenment neo-classicism, however, differs from Renaissance classicism: given as its predecessor (Cartesian/Lockean) scientism, with its stress on finding own information, it will not, like the Renaissance scholars, accept Classical works as sources of information; instead, the Enlightenment idealises the Classical 'humanist' way of doing things, and will take famous Classical works as normative models (in combination with the sources of information of its own day). Hume's competition-survival standard of quality in the arts practically implies precisely this kind of (Neo-) Classicism; and Adam Smith's moral standards - the aims of nature - are derived from Classical sources. This is not a strong feature in Kant, but (strictly speaking) he does not belong to the Enlightenment as a movement.

\section{ADAM SMITH AND CAPITALIST ECONOMICS}

\subsection{Smith and the Enlightenment}

One of the classics of Capitalist theory is still Adam Smith's An Enquiry into the Nature and Causes of the Wealth of the Nations (1776). Although Smith is known to us as the founder of theoretical economics, his university chair in Glasgow was that of a philosopher: he taught ethics and logic (and included his early economic thought in his ethics course, under the headings, "Natural Jurisprudence" and "Politics"). Smith thus started his academic career as a philosopher in Enlightenment context - as will be shown more clearly in our discussion of his economics.

Alithough the relationship between his early work, Theory of Moral Sentiments (1759) and An Enquiny into the Nature and Causes of Wealth of the Nations has been the subject of dispute, some of the themes which we find in mature form in An Enquiry into the Nature and Causes of Wealth of the Nations, are already present in his earlier work, and are rooted in the Enlightenment. According to his biographer, he had, by 1755, already accepted the idea that nature guided human affairs in a teleological way, using economic growth as the base of social progress. Thus governments had better leave it to the citizens to care for their own needs under the guidance of nature (Cannan, in 
Smith, 1776:xxxv). By 1759, in the Theory of Moral Sentiments, he exhibits a welldeveloped sense of freedom, probably following his teacher, Hutcheson, but rejecting the latter's acceptance of benevolence as a prerequisite for a free society, arguing that specific recognised virtues (such as saving, working hard, etc.) have their roots in selfinterest, whilst their opposites are being frowned upon (Manenschijn, 1979:124-6; Cannan, in Smith, 1776:xli-xlii). He also defended freedom in the form of selfinterest against Bernard Mandeville's satire, The Grumbling Hive, or, Knaves Turn'd Honest (1705/1714/1729), saying that Mandeville too easily represents what does not belong to ascetic sobriety or stoic apatheia as selfishness, hypocrisy, and evil, and uses this to establish his favourite conclusion that private vices are public benefits (Smith, 1759:485).

Thus Smith shares with the Enlightenment the special interest for the ambivalent role of nature, which, in Smith's usage, can mean anything from "that which is on hand", to "the normal", or "that which happens according to norm" (Manenschijn, 1979:218). It is also clear from his enthroning of self-interest that we ought to expect from him a social theory with competition of interests at its basis, and that he thus shares the Enlightenment dialectics of individual versus society. His theory of progress is that of a gradual advance towards the dominance of reason, but, given the level of development of mankind (in his day), he stresses the primary role of the passions, which guide us in following a justified measure of self-interest. In other words, if every person cares for his own survival and that of his kin, society will make progress independent of individual intentions, and fairness will come about through the equilibrium of contract. His moral ideals are those of the peripatetic intellectual, who represents the highest level of morality, in which benevolence reigns, thus - though in a subdued way - Smith does find his normative ideal for a moral society somewhere in Classical antiquity.

\subsection{Smith's ethics}

Although Smith accepts Hutcheson's leibnizian idea of a cosmic harmony, he maintains that we are not able to interpret it in a moral sense. Thus he separates God's final causality (the teleology of nature) from human efficient causality (taking care of one's affairs and propagating the species; Smith, 1759:292). If we, however, do our very best regarding the latter, we unknowingly contribute to the execution of Providence's plan for the human species (1759:166).

This separation allows Smith (about 1750) to develop theories of morality and economics in a practically mechanistic way (in spite of a macrocosmically organistic 
approach). This tendency to mechanism dates from Smith's early interest in Newton, seen in his essay, The Principles which Lead and Direct Philosophical Enquiries Illustrated by the History of Astronomy (about 1750) in which he uses the concept of agreeability (also used in his ethics to indicate the morally positive) as the (gravitational) equilibrium state of the imagination in theory formation (Smith, 1980:45-6). The concept of agreeability for the imagination and the feelings, as well as the idea of gravitation towards an equilibrium, is given a central role in both Smith's ethics and his economics. Thus these theories acquire a mechanistic appearance akin to those of Darwin and Freud, and much more 'naturalist' than, for example, Hume's (competition-based) views on art (as analysed in Verter, 1992?).

Smith (1759:31ff) 'baptises' self-interest (called "selfish passions") in the face of Hutcheson and Mandeville by according it a midrange area between the social and the unsocial passions. Self-interest is subjected to the judgement of the impartial spectator - a proto-freudian internal, imaginary-objective super-ego, who judges, under the guidance of agreeability, according to the rules of prudence (longterm self-interest) and justice (social interest) - so as to avoid conventionalism (seeing that the individual becomes a moral creature only through society), as well as arbitrary, individualistic sentimentalism (1759:130-159).

Moral rules are not discovered by reason, which is limited to finding agreeability only indirectly through recognition of utility - they are directly 'intuited' by the (hedonistically conceived) sense of agreeability or disagreeability of immediate feeling:

Though reason is undoubtedly the source of the general rules of morality ... it is altogether absurd ... to suppose that the first perceptions of right and wrong can be derived from reason ... Reason may shew that this object is the means of obtaining some other which is naturally either pleasing or displeasing, and in this manner may render it agreeable or disagrecable, for the sake of something else. ... If virtue, therefore, in every particular instance, necessarily pleases for its own sake, and if vice as certainly displeases the mind, it cannot be reason, but immediate sense and feeling, which in this manner reconciles us to the one and alienates us from the other (Smith, 1759:16).

Smith apparently chooses sensualist hedonism instead of Hume's utilitarianist hedonism. Reason as the detector of utility can only bring about an indirect hêdonê, and as the formulator of general rules it can only do so on the basis of repeated direct experiences of hêdonê. He seems to approach Mandeville in his denial of a rational basis for a progressive society, only substituting the sensual for Mandeville's 'evil'. This kind of 'irrationalism' in an age of reason seems very strange. We, however, must keep in mind that Smith was looking for a mechanism of automatic progress, working on the 
basis of gravitational constancy, and that, given the fact that reason is the highest faculty of man, progress also encompasses the growth of rationality and freedom (cf. also Raphael, 1975:97). Thus Smith latches onto the physicalist constancy and immediacy of the interaction of passions to gain insight in the supposed laws of supposed progress. Smith seems, as the Marquis of Condorcet also did, to assume an analogy between the development of the individual and that of mankind. A child grows through the pleasure/pain phase into the emulation phase (in which his behaviour is determined by the passion for out-shining others), and ends up as a mature human being in the phase of virtue (in which not the praise of others, but the praiseworthiness, determines his behaviour) (1759:41ff., 114-7, 145ff.). From the latter point of view, the mature human being rises above group morality. For, in general, society functions at the emulation level, with ambition as its driving force, but man's conscience is not bound to this.

Of course we can transcend the emulation level: the individual 'Peripatetic' or 'Academic' to superprudence (which consists of prudence, sanctified justice, and benevolence); society to 'Epicurean' benevolence (composed of justice and embellishment) (1759:216) - this is the Classicist ideal in Smith's ethics.

The latter two levels of moral progress (namely the virtue and the emulation phases) reflect the parallel of reason and passion, and provide for two social orders, being roads to the same (natural-teleologically determined) end - the one via wisdom and virtue; the other via the accumulation of wealth and greatness (1759:170). Smith clearly anticipated Marx's base - superstructure model in accepting that cultural growth is dependent upon the accumulation of material goods.

For the time being man is at the second level - that of 'accumulation'. Although the higher (rational) road is ethically preferable, Hutcheson was mistaken in thinking that only benevolence could be the basis of a moral society, for a society may subsist on the basis of the utility of exchange:

Sociely may subsist among men, as among different merchants, from a sense of its utility, without any mutual love and affection; and though no man in it be bound in gratitude to any other, it may still be upheld by a mercenary exchange of good offices according 10 an agreed valuation (Smith, 1759:86)

Note the exchange/hawker/barter metaphor in Smith's explanation of the basis of society. This metaphor binds Smith to the contract-idea of society, as expressed by Rousseau and Hobbes. Bartering, according to Smith's economic theory, is basically human and basically contractual. Smith presupposes that just as the astronomical 
system is maintained by the interaction of gravitational forces, so the whole of society is ordered by the equilibrating forces of contract in exchange (whether it be emotions, good offices, or goods). The latter seemingly forms the basis of social cohesion; the society which he has in mind is energized by ambition: anticipating Veblen's theory of the leisure class, Smith states that progress is caused by the poor wanting to live as the rich do. The passion of ambition, if tempered by prudence and justice, is always admired (1759:173). In An Enquiry into the Nature and Wealth of the Nations (1776) Smith gives us this theory of social cohesion and progress. This is the only way to explain the existence of society at all, once one has given up on every humanitarian form of social cohesion (like love, friendship, family obligations, etc.) as explanatory.

\subsection{The foundations of economics}

Having read the Theory of Moral Sentiments, one knows that the foundational role of selfinterest - as maintained in An Enquin into the Nature and Wealth of the Nations, serves for more than just getting bread on the table. The creation of wealth is one of the ways to fulfil the goal of man. Benevolence is in itself not able to sustain the cohesion of society and provide for the survival of the individual, for human beings, unlike other animals (and in this Smith follows Hutcheson) cannot survive without the assistance of other human beings, but can also not depend on their benevolence for own survival. Thus Smith falls back on the self-interest principle as a mechanism of survival, and 'to survive' here practically means 'to survive together':

But man [in contrast to the other animals - JJV] has almost constant occasion for the help of his brethren, and it is in vain for him to expect it from their benevolence only. He will be more likely to prevail if he can interest their self-love in his favour, and shew them that it is for their own advantage to do for him what he requires of them. ... It is not from the benevolence of the butcher, the brewer, or the baker, that we expect our dinner, but from their regard to their own - interest. We address ourselves, not to their humanity but to their self-love ... (Smith, 1776:16).

In survival terms, man is by nature a hawker. That we have specialisation among men is natural, being a gradually realised consequence of bartering. Thus as Rousseau, and later also Marx, has it, man is originally unspecialised; from them Smith (1776:15) differs, however, by expressly appreciating specialisation as a good consequence of human nature: it is the necessary consequence of the uniquely human propensity to truck, barter and exchange (Smith, 1776:15).

Smith seems to give some credit to practical reason and the organs of communication for enabling mankind to live up to its bartering nature, and it is surely difficult to 
imagine how interests can be weighed and conditions set without logic (i.e. determining of utility) and speech (coming to agreement on terms). Reason, for Smith, is the 'organ' which provides insight into the means for agreeable ends, and thus has to play some guiding role in the bartering process (which has a means-ends structure). In this he approaches Hobbes' idea that rationality is self-preservation manifested in the concluding of contracts. But for Smith contracting in the sense of bartering is natural to man even in his primitive state (which Hobbes may have denied). Thus the possibility of specialisation is there very early, to assist man on his way to civilisation. It is this which determines the differences amongst human beings: the genius is the product, not of nature, but of culture (habit, custom, education), through specialisation (1776:17-18). (Marx later copied this without acknowledging the source!)

In general, although Smith joins Hutcheson in stressing the essentiality of co-operation amongst individuals, he has a different idea concerning the foundations of co-operation: instead of Hutcheson's benevolence he proposes self-interest, as expressed in exchange. But, importantly (and the principle of specialisation implies this): behind the bartering process lies the labour of the seller which determines at what rate he will be prepared to part with the product of his labour. The higher his input of troubles or expertise into the product, the higher the price will be (Smith, 1776:49).

Smith's theory of prices has its roots in a view of man's historical development. Like many other Enlightenment thinkers, Smith (1776:49-50) applies reverse extrapolation to determine the course of this development:

In the advanced state of society, allowances of this kind, for superior hardship and skill, are commonly made in the wages of labour; and something of the same kind must probably have taken place in its earliest and rudest period. In this state of things, the whole produce of labour belongs to the labourer; and the quantity of labour commonly employed in acquiring or producing any commodity, is the only circumstance which can regulate the quantity of labour which it ought commonly to purchase, command, or exchange for.

Price formation in the advanced state of society is, of course, much more complex, and has at least to provide for the rent of land and profits of stock, over and above the wages of labour. In this case the labourer does not own the whole produce of his labour, but shares it with those who receive the other components of the price, i.e. the landlord and the capitalist (Smith, 1776:51). (Again Marx finds a direct handle on Adam Smith - by using the same reverse extrapolation, and romanticising the original, unspecialised man as labourer, he could expose the injustices of capitalism very sharply.) 
Smith calls the price thus determined the natural price, to be distinguished from the actual or the market price. The latter is determined by supply and demand, where 'supply' and 'demand' are actually only names for two kinds of competition (1776:58).

It is important to note that there are two kinds of equilibrium of exchange involved here. Firstly, there is the market equilibrium, where supply equals demand, and secondly, there is the natural equilibrium (at the level of the natural price), the point above which the producer will tend to push, and below which the buyer will tend to push the price of the product. The quantity of supply and demand - thus competition will determine the respective effectivity of their pushing and pulling - i.e. contracting. The natural price is therefore something like the centre of a planet: the point to which smaller bodies tend to 'fall'. Note Smith's terminology (1776:60) in this regard:

The natural price, therefore, is, as it were, the central price, to which the prices of commodities atc continually gravitating. Different accidents may sometimes keep them suspended a good deal above it, and sometimes force them down even somewhat below it. But whatever may be the obstacles which hinder them from scttling in this centre of repose and continuance, they are constantly tending towards it (my italics - JJV).

Smith's theory of the natural price expresses the anthropocentric way in which Enlightenment thinkers used to speak about nature. It concerns human interests in the bartering situation, and yet functions as superhuman absolute for price formation. The natural price, set in the gravitational metaphoric model, implies a difficulty. Smith believes in progress, which for him implies that the poor masses will imitate the rich few, and exert themselves to attain the same level of wealth. But as they have only limited means to compete, their influence on effective demand is not strong, and competition will always neutralise their progress by the tendency towards equilibrium. And as Smith accepts the teleological idea of nature, he assumes that intervention by society will inhibit rather than promote progress. Thus this model, consequentially, seems to point to stagnation rather than upliftment. The only way, seemingly, to make a breakthrough here, is for the rich to spend their money on useless and vain things, so as to widen the scope of employment: if Smith does not want to buy greed from Mandeville, he will have to buy extravagance. (Given the assumed greed for accumulation of capitalists, savings will theoretically be assumed as immediately re-invested.)

As can be derived from the above, Smith is prepared to accept the striving for luxury as something positive in teleological terms. But Smith's mind is not fully at rest about the urban society of his day. Already in Theory of Moral Sentiments (1759:50-66) he despises the lifestyle of the rich, for they corrupt moral sentiments by despising and neglecting the poor (especially in the exchange of passions). He proves to be an 
agrarian capitalist who sees in human nature not only the barterer, but also the farmer. In the 'primordial' life of agrarian simplicity, much of the evil of urban and international trade is eliminated. Although difficult to believe, the same man who propagates progress through ambition, wrote romanticising passages on rural life (cf. 1776:356-7). With Rousseau, Smith apparently finds the/a source of corruption in human institutions, and longs for some 'primitive' harmonious relationship with nonhuman 'nature'. But even in this longing Smith stays capitalist. The cultivation of land does not only provide the most secure investment for capital, but also produces the highest profit, and thus the added value of investment in agriculture is, for society at large, the most advantageous of all investments (1776:344).

We should, in fact, not be surprised by this (sudden) quasi-romantic longing for paradise. Even in this Smith is part and parcel of the Enlightenment. The tension between nature and culture, between origin and progress, expresses itself also in his thought. And as is the case with Rousseau, so also with Smith: the evils of institutionalised life and glitter fulfil a necessary role in the advance of mankind. The farmer cannot cultivate his land without artificers to make and repair his tools for him; the artificers themselves need one another, as well as bakers and butchers ... And so towns develop as a necessary concomitant to the development of agriculture. From this develops commerce, first locally, then internationally. Smith (1776:359) sees this development from agriculture to local manufacture, and then to foreign trade, as "the very natural order of things", but complains that in 'modern' Europe this order had been inverted. In this case foreign commerce had determined the products to be manufactured, and the latter again had lead to "the principal improvements" in agriculture. By now one can guess what Smith's explanation for this would be: the state/the government created this unnatural and retrograde coercion.

Our analysis of Smith's doctrines has ended more or less where we started: with the opinion that there is a natural order of progress which ought to be left intact by human institutions, and that the natural progress will be served much better if everybody were left to care for his/her own interest. This implies that the progress of society - a progress towards rationality and benevolence - is seen to be the product of competition of interests, of which the worst effects are neutralised by different kinds of equilibrium of exchange, both on the emotional (moral) and on the economic level. 


\section{IMMANUEL KANT AND CULTURAL PROGRESS}

\subsection{Kant and the Enlightenment}

Usually Kant is analysed from the point of view of the three critiques, and very often only the Critique of Pure Reason comes under focus. Kant has, however, left behind certain small treatises on the philosophy of history and politics, which have only recently begun to command the attention of the broader philosophical community. These treatises, in which some (otherwise) hidden foundations of his thought are exposed, appear almost as confessions of faith on Kant's side. They quite clearly reveal Kant's roots in the life-view of the Enlightenment. This does not imply that Kant can simply be treated as an Enlightenment philosopher, but rather that Enlightenment ideas had polluted the intellectual environment, and were picked up by Kant.

The supposition of a pollution of ideas forces us at least to date Kant with reference to the Enlightenment. Of the famous Enlightenment authors, Voltaire was a senior: born in 1796, he died in 1778; his works appeared between 1734 and 1764. Hume was born in 1711 and died in 1776; his chief works being published between 1739 and 1761 . Rousseau was a year younger and died in 1778; his major publications appeared between 1752 and 1762. Adam Smith was born in 1723 and died in 1790; the Theory of Moral Sentiments was published in 1759 and the Enquiry into the Nature and Wealth of the Nations in 1776. Kant was a contemporary of Smith, but lived somewhat longer: born in 1724, he died in 1804; his major works appeared very late, the first critique in 1781, the second in 1788, and the third in 1790 . The four treatises which $I$ intend to focus upon appeared between 1783 and 1795 . Thus it is clear that there was ample time for the pollution of ideas to have taken place before Kant's major works or these treatises could see the light; his critical idealism in fact cohered with the Enlightenment's basic tenets (possibly excluding its Neo-Classicism).

The treatises which I have in mind are the following:

- Beantwortung der Frage: Was ist Aufklärung? (1783)

- Jdee zu einer Allgemeinen Geschichte in Weltbürgerliche Absicht (1784);

- Mutmasslicher Anfang der Menschengeshichte (1786);

- Zum Ewigen Frieden (1795).

With the Enlightenment Kant shares the following themes: Firstly, the central role of 'nature', conceived of as teleological and anthropocentric yet transcending man; the dialectical tension between nature and culture (sometimes specified as instinct versus 
reason); the belief in progress; and the use of the conflict/competition motive as mechanism of progress. Although reason is the source of autonomous choices (which later represents the real Enlightenment emancipation of man), it does so unknowingly under the guidance of nature, which uses man's limited specialisation and the struggle for survival, to enforce the progress of the species. Kant believes, however, that nature's evil means will eventually be neutralised by an equilibrium; a balance of powers which will automatically maintain itself - eternal peace. It should be clear that Kant's conception of cultural progress is structurally very near to Adam Smith's views on economic progress. The teleology of nature, however, is much more 'up front' in Kant - a characteristic which intensifies the dialectics between autonomous reason and nature, and between individual and species.

\subsection{Kant's life-view}

Those who are acquainted with the contents of Kant's three critiques may have a representation of Kant's thought in terms of an 'ontology' of 'consciousness' or 'reason'. We have a picture of a three-storeyed consciousness, with the imagination as ground " floor, the understanding as the first floor, and judgement on the top floor. The materials of cognition are progressively synthesised or unified by the faculties inhabiting each storey. This structural model is used to explain the limits of scientific knowledge, to provide for a critique of metaphysics, and to explain judgement and praxis. It is, however, all too often not realised that this ontology of consciousness did not stand on its own, but was embedded in the framework of the Enlightenment worldview, specifically its views on history and progress. Consciousness is subject to the dominance of either instinct or reason depending on the level of advancement. In other words, imagination, understanding and judgement either perform their duties under the government of instinct or of reason.

The domination by instinct is characterised as slavery, that by reason as freedom; instinct is directly connected to nature, reason to culture. Progress moves from the instinctual to the rational, provided that we keep in mind that the progress of the individual is not exactly analogous to that of the species, and that certain activities (like art) are naturally instinctual, whilst others (like science) naturally lend themselves to accepting the guidance of reason. And the whole history of mankind is under the inescapable government of nature, aimed at this very progress.

Thus we have to look at the history of man's progress. 


\subsection{The method of a philosophical historiography}

When Kant writes about the history of man, he applies specific norms of a rational historiography, searching for a system, a kind of regularity in human behaviour. This approach is not out of tune with the approaches of his contemporaries or near predecessors (e.g. Hume, Smith, Hobbes, Vico, Condorcet, etc.).

Within Kant's basic distinction, there is, apparently, room for two opposite kinds of system, namely the rational versus the natural. And given that human freedom (although the product of reason) does not seem to follow any rational pattern whatsoever, Kant assumes a natural pattern for $i t$, rather than no system at all, which means that historical succession is supposed to take place according to a plan of nature. This has two implications:

- the course of history is not determined by conscious decisions of man, but rather according to natural law;

- nature is seen in an anthropomorphic or even theomorphic way as guiding the world according to intention.

Regarding the first, Kant (1784:33) is very explicit:

It does not matter how we metaphysically conccive of the freedom of the human will; the appearances thereof, namely the actions of man, are determined under the force of natural law, precisely like every other natural event. ... (Kant refers to the regular patterns shown by population statistics, and continues:] Individual people, and even whole nations, do not often think about the fact that they, while striving - every one in his own way and often in conflict with onc another -, cach for his own goal, unconsciously follow the goal of nature (which is unknown to them), as if they are on leading-strings, and are involved in the promotion of that which, if it

- were known to them, would not have much significance for them.

And though - touching the second implication - the people do not know what nature intends with or for them, Kant does know, and we could summarise his knowledge in one word: progress! Or, as Kant himself expresses it (1784:35,45; cf. also 1786:92):

It has been detcrmined that all natural abilities of a creature will one day develop themselves fully and cffectively. ... In man, as the only rational ereature on earth, the special natural abilitics aimed at the use of his reason, need only develop fully in the species, not in the individual. ... We can regard the histury of the human species in general as the execution of a hidden plan of nature, to create a perfect legal order, both within and amongst states, as the only situation in which it can develop all its abilitics in mankind. 
The belief in progress, underscored by the reference to statistics and bound up with strict natural law, does remind one of the work of the Marquis of Condorcet. The works of a man of wide reading, like Kant, become a microcosm of the literature of his time - unfortunately Kant neglects specific references to his sources.

Few people know that Kant left us with his own commentary on the history of man according to the Genesis account, entitled Mutmasslicher Anfang der Menschengeschichte (Presumed Start of Human History)(1786), in which he tried to reconstruct human progress from its origin. Methodologically he follows the reverse extrapolation procedure characteristic of Enlightenment attempts at reconstructing 'natural man', on the the supposition of the uniformity of anthropocentric nature (as if transferring the geological methodology of his contemporary, James Hutton (1726-1797) into human studies), stating that it is possible to delve into past experience on the presupposition in tune with the analogy of nature! - that experience was neither worse nor better in the beginning than 'now' (1786:85).

As a disclosing guideline for the early history of man, Kant accepts the 'holy charter' (the book of Genesis), but allows himself the freedom of "a journey ... undertaken on the wings of imagination, although not without a guideline bound by reason to experience" (1786:85-6). Although quite playful in his approach, and yet quite submissive with regard to the authority of his 'holy charter', Kant's presuppositions almost guarantee that orthodox Jews and Christians will probably not agree with his reading of Genesis 2-7. In fact, his flight of presumptive fancy results in reading Enlightenment philosophy of progress into Genesis, which makes it almost unrecognisable from the orthodox point of view.

Kant periodises human progress from a peaceful, but instinctual start, to a peaceful, but rational end. The interim, however, is characterised by misery and conflict. In Mutmasslicher Anfang der Menschengeschichte (Presumed Start of Human History (1786) he distinguishes three periods:

* the dominance of instinct and the awakening of reason;

- the development of labour;

* the development of an urban way of life.

In line with the Idee zu einer Allgemeine Geschichte(1784) and Zum ewigen Frieden (1795) one could distinguish a fourth period in Kant's historiography, namely the development of nations, which ends up in a league of nations under international law. Since this development is motorised by the mechanism of conflict, which implies the rise and fall of nations and civilisations, Kant has to find a special methodological prin- 
ciple to guard progress through successive collapses of civilisation. For this purpose, he (Kant, 1784:48-49) uses an analogue of the catastrophistic method - used by another contemporary, the biologist Bonnet (1720-1793), to explain the transformation of miniatures (embryos) into higher species - to interpret the progressive succession of civilisations:

\begin{abstract}
As long as one only pays attention everywhere to the civil legal order and its laws, - in so far as both, by the good which they contained, served for some time to uplift and glorify nations (and with them also the arts and sciences), but also caused them to collapse, because of the shortcomings inherent in them (but yet in such a way that there always remained a germ of enlightenment, which, developed further by each revolution, prepared another, even higher phase of the development) - then , I think, a guideline will reveal itself, which can serve not only to explain such a confused play of human affairs ...
\end{abstract}

Of course a history which shows the almost cyclical rise and fall of nations and civilisations, does not in itself provide hope. But hope is methodologically built into the system by using the metaphor of bonnetian catastrophism in terms of the plan of nature. Thus one cannot only uniformly extrapolate to the beginning of history, but also predict the future chiliastic state in spite of all catastrophies that may befall mankind.

\title{
3.4 Animal versus rational
}

We have, next, to ask what Kant's views on historiography and progress specifically implied for his treatment of man in history. Three aspects are of significance here.

* Firstly, Kant treats man in a naturalistic way (as an animal), or rather explains his historical actions from the perspective of his animality.

- Secondly, man's progress is a progress towards greater rationality, peace and a moral society, i.e. man becomes something more than an animal, but by virtue of his animality.

- Thirdly, the mechanism of progress is none other than conflict/competition, eventually neutralised by the equilibrium of contract.

As to the animality of man Kant is very explicit, to such an extent that Darwin could have learnt something from him. Nature, having placed the full development of his 
natural abilities in the ('eschatological') Idea of man, has also equipped him in such a way that he is forced to the autonomous development of his highest faculties. By limiting man's animal capabilities, it forces him to use reason, and to uplift himself above the mechanical order of his animal existence (1784:35-36), in such a way that man will only have himself to thank for his progress (1784:36-37).

In this context (and related ones), Kant has no qualms in summarily referring to man as 'animal' (German: Tier), e.g.: "one kind of animal ought to have reason" ("ein Tiergattung soll Vernunft haben", 1784:37), "man is an animal ... who needs a lord" ("Der Mensch is ein Tier ... das einen Herrn nötig hat", 1784:40).

The contrast between the natural and the cultural, instinct and reason, is in itself an indication of Kant's naturalist approach to man. This is clear from the way in which Kant treats man's progress from animality to rationality, which is the second aspect we have to focus on. We find this explicitly in the Mutmasslicher Anfang der Menschengeschichte (Presumed Start of the History of Man). In this booklet Kant, as has been mentioned above, divides the history of man into periods, of which the first, up to the fall of Adam and Eve, is interpreted as the initial progress from animal instinctuality to human rationality. Man is initially guided by that voice of God which all animals obey: instinct (1786:87). No 'metaphysical' instinct is intended: Kant thinks in terms of pure sensuality under the guidance of nature. One is almost surprised that he found it possible to start with a thinking, talking, human being, for Kant's Adam is barely on the level of a pet dog.

But happily, this first phase is also the phase of the step-by-step awakening of reason, which will show itself as the 'faculty' of freedom. Reason quickens in four steps:

- Reason lifts its head and with proto-existentialist anxiety attempts alternatives to the food prescribed by instinct:

But: it is a characteristic of reason that it can conjure up desires with the help of imagination, not only without a related natural drive, but even against it. ... That which gave occasion to infidelity towards the drives of nature, may have been something small, but the effect of the first attempt, namely becoming conscious of your reason as an ability that can transcend the boundaries within which all animals are kept, was very important and decisive for the way of life. .. man's eyes were opened because of it (Gen. 3:7). He discovered in himself the ability to choose a way of life for himself, and not to be bound to one only, like other animals (1786:87-88).

- Reason learns that it can dominate and strengthen the instincts and set ideals for them, thus moving in the direction of moral decency, by, for example, postponing sexual satisfaction or removing its object from the senses: 
The fig lcaf (Gen. 3:7) was the product of a much bigger expression of reason ... For to intensify and expand the duration of an inclination by withdrawing its object from the senses. already

shows the consciousness of a certain dominion of reason over the drives .... (1786: 89-90).

* Man having realised his ability to transcend the purely sensual and live a (possibly moral) life guided by the Idea (1786:89-90), reason now begins to represent the future, thus enabling man to set goals for himself, but at the same time creating typically human fears for the future (and death), neutralised only by family comforts and an expected better life for one's offspring (1786:90).

- Reason is fully awakened in man in understanding that - in contrast to all other animals, all of them instrumentalised by man - he himself is no means but an end in himself, not to be instrumentalised by anybody. Thus man is elevated to "a certain equality with all rational beings, to whatever rank they may belong (Gen. 3:22)" (1786:91). This step implied the release of man from the womb of nature, a banish ment' into a dangerous world, where he, in the face of obstacles and crises, will often long to return to an imagined paradise. But no chance: the restless reason prevents such a return and drives man towards the development of his inherent abilities, through hateful labour, ignoring approaching death (1786:92).

Thus the first period of human history comprises the awakening of reason, firstly as additional option, secondly as governor of the sensual, thirdly as setting goals for future realisation, and fourthly as recognising himself as goal, the latter of which signifies rational man's attainment of independence. In this way the 'primate', Adam, progressed to the state of homo sapiens.

The characteristics of the Enlightenment analysed above are clearly visible in Kant's summary (1786:92-92) of this progress:

This cxposition of the history of the first human beings results in this: that the exit of man from paradise, which was proposed to him by reason, as the first sojourn of his species, is nothing but the transcendence from the rawness of a simple animal creature to mankind, from the crush-pen of instinct to the guidance of reason, in short: from the guardianship of nature to the status of freedom. If we look at the destination of the natural species - which consists in nothing clse than the progress to perfection ... then it cannot be asked anymore whether man has lost or gained by this change. In the meantime this process, which for the species means progress from the worse to the better, is not precisely the same for the individual. Before the awakening of reason, there was neither commandment nor prohibition, and thus no transgression. Once it started with its task, and wcak as it was, had to contend with animality in its full power, disasters, and what is worsc, as reason became more cultivated, licentiousness had to follow, which was 
totally foreign to the state ignorance (and thus innocence). ... The history of naturc therefore started out with the good, for that is the work of God; the history of freedom with evil, for that is the work of man. ... the inevitable conflict of culture with the nature of the human race ...

The point which Kant makes about the progress of mankind is that it does not end with the awakening of reason. The domination of man by reason is itself under the guidance of nature towards the goal of a moral society, for only in that situation can nature attain the full development of man's potential. (Vaguely Kant does have some 'new Jerusalem' notion for man in mind.) The quote exhibits the typical Enlightenment ideas of an anthropocentric and teleological nature, the not-so good as an instrument or mechanism of progress, and the tensions of nature versus culture, and individual versus society/species. As these will sporadically show up in the discussion of the mechanism of progress, the conflict/competition motive, we shall not accord them a separate discussion.

\subsection{Conflict/competition and the civil order}

Kant shares conflict/competition with the Enlightenment as the mechanism of progress. As mentioned above, Kant (like Adam Smith) believes that man can only become a moral being via society. Thus he needs some firm foundation for the establishment of society, which can also serve as the driving force or instrument of pressure, to keep mankind on the road to self-development.

\footnotetext{
The means which nature uses to establish the devclopment of all his talents, is their antagonisms in society, in so far as these in the end nevertheless become the cause of the legal structuring of society. By "antagonism" I mean the unsocial sociability of man, that is, his inclination to socialise, which is nevertheless bound up with continuous resistance against it, of which the latter constantly threatens to brcak up society. The aptitude for this is visibly present in human nature. ... It is precisely this resistance which awakens all human power and brings him to the point of overcoming his inclination to laziness, and driven by ambition, imperiousness and greed, to acquire a status for himself amongst his fellows, which he does not like, but cannol sct aside From this the first true step out of rawness of nature to culture (which actually consists in the social value of man) happens; ... talents ... develop; ... the beginning of a way of thought which can transfer the crude natural ability to moral distinction ... into a moral whole (1784:36-7).
}

These words could also have been written by Adam Smith, or rather, Smith may have found them too naturalistic to describe his farming hawkers, for they lack the nuance of Smith's midrange between social and unsocial. Even their author felt somewhat uncomfortable about the harsh mechanism of progress which he had chosen. One should imagine that Kant wrote for a public which had been exposed to Christianity, and that 
the mechanism of progress which he proposed, represented the very opposite of what Christianity had taught them as the basis of human relationships (namely: love, even for the enemy, self-sacrifice, solidarity with the poor, modesty, defencelessness). Thus Kant tries to justify the means by the ends - in the name of God: nature, using the unsociability of man, forces the human species to uplift itself (although this produces catastrophies for the individual), and betrays the ordination of a wise Creator, wishing the full development of the natural taients of man as species! (1784:39).

It is the danger which this unsociability represents that forces people to enter into a legally ordered society. For the moral development of man, a society is prerequisite in which the maximum amount of freedom is balanced with such limitations of freedom as is needed for the different individual freedoms to co-exist (1784:39-40). In other words: outright conflict must be brought under control, that is, transformed into regulated competition. In Mutmasslicher Anfang der Menschengeschichte Kant represents this socialisation of man as one which started out with the conflict between agriculturalists and herdsmen, and later between townsmen and nomads.

This second period of human history sets in with the change from leisure and peace to labour and discord. Some people preferred the easy life of the herdsman, respecting no boundaries or property. Others involved themselves in the laborious lifestyle of agriculture, for which property and boundaries were prerequisite. This conflict of interest leads to the separation of the nomadic herdsmen from the established farmers, the latter founding townships for the sake of the defence of their property and persons. This of course leads to exchange, culture, (uncontrolled) government, even an elementary civil legal order, the arts of sociability and civil security, and notably of inequality the source of so much evil, but also of all good - which can lead to despotism. Despotism is only limited by war (!), for war requires wealth which is only created under some measure of freedom (1786:97). This freedom is immediately lost, however, when the nomads are integrated into urban life and the threat of war disappears. Freedom is replaced by licentiousness and slavery - a situation analogous to pre-Enlightenment man's immaturity, due to laziness and cowardice in using his own understanding independently (Kant, 1783:53).

One seems to have here some combination of the ideas of capitalism and of Machiavelli. The latter propagated the idea that the challenge of war leads to the expansion of privileges for the common people, and that inequality and conflict of interest within the boundaries of a republic, were necessary for the preservation of freedom (The Discourses, 1979, 1:4-6), whilst the former, at least as Adam Smith will have it, argues that wealth is only created where we have the least possible government intervention in the lives of private individuals. 
The principle of conflict/competition also takes care of international relations. In fact it is important that some kind of control of international conflict be found, because the moral progress of man and the full development of his abilities depend on his not being involved in conflict so deeply that it will obstruct his cultural development, whilst also not having so much security that he will not exert himself at all, and simply accept immaturity and tyranny (Kant, 1784:45-6). What is, however, really needed is a situation of contractual equilibrium, analogous to the legal order within a state. This will in a way come into being all by itself, for a time will arrive when the advantages of war will be overshadowed by its disadvantages, and mankind will be forced to accept an international legal order in the form of a league of nations:

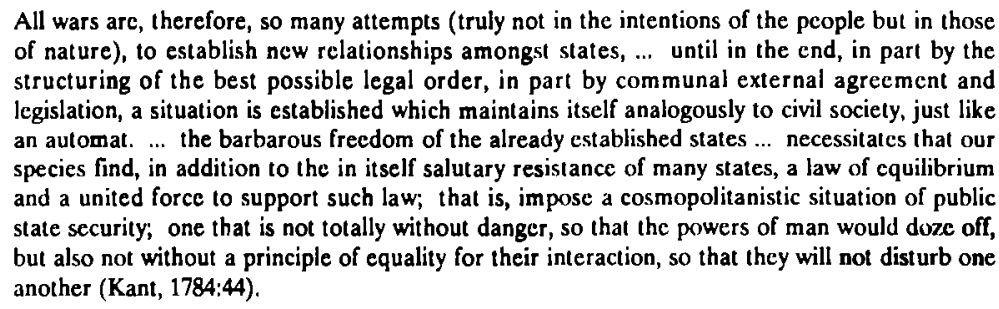

All wars arc, therefore, so many attempts (truly not in the intentions of the pcople but in those of nature), to establish new relationships amongst states, ... until in the end, in part by the structuring of the best possible legal order, in part by communal external agreement and legislation, a situation is established which maintains itself analogously to civil society, just like an automat. ... the barbarous freedom of the already established states ... necessitat es that our species find, in addition to the in itself salutary resistance of many states, a law of equilibrium and a united force to support such law; that is, impose a cosmopolitanistic situation of public state security; one that is not totally without danger, so that the powers of man would doze off, but also not without a principle of equality for their interaction, so that they will not disturb one another (Kant, 1784:44).

The 'constitution' for this proposed international legal order is set out by Kant in Zum Ewigen Frieden. One might say that this is the fourth period of the history of mankind the 'new Jerusalem'. Generation after generation are working for this: vaguely, or not at all, conscious of it, they are involved in the improvement of the situation of their offspring, and very often this is the only comfort they can find (Kant, 1786:90; 1784:37).

The naturalistic harshness and the regime of conflict in Kant's view of the history of mankind, could, in itself, only provide the causes of psychological depression or philosophical pessimism. Amidst a history of revolution, catastrophe, ambition, lust for power, greed, vanity, the only ray of hope could be the expectation of a better future for their offspring. In a context where rationality itself uses evil (towards some unseen good), one has to trust nature to provide that better future, nay, to impose it by the force of natural law, and so the mechanistic model of equilibrium is found. But Kant is also the Kant of the three Critiques: the Kant who believes in autonomous reason. Even for that nature has the solution: the animal equipment of man is so limited that he is forced to use reason, and thus he can still pat himself on the shoulder for his progress. 


\section{CONCLUSION}

Collecting the results together in a summary comparison, we may conclude the following:

Adam Smith sees a multi-storeyed relationship between the rational and the lower faculties (eg. the passions). Reason, for him, is slow and indirect, and cannot provide us with immediate insight into moral norms. Decisive for Smith is the passion for selfinterest, and the emulative level on which the majority functions. The main road of progress, which will end up with a rational situation, is based on the contractual, bartering, self-interested character of man. In fact, even the impartial spectator (Smith's proto-freudian figment) judges (rationally, imaginatively) according to the longterm self-interest of the individual, weighed against the social interests. When everybody cares for his own interests, nature will care for the advancement of the totality: Smith has a teleological view of nature (totality), but prefers to focus on the individual's self-interest. Given the latter, Smith supposes a Newtonian 'gravitiational' equilibrium point (e.g. the natural price) to which competition (the survival motive of the contracting parties) will naturally force these parties. He supposes economic progress to be the base for cultural progress. This, of course, might be in jeopardy if equilibrium were not constantly forced to disequilibrium by the needs of the rich; specialisation and capitalist desire for accumulation prevents the process from stagnating.

Kant went much further than Smith. He dialectically embedded autonomous reason into the mechanistically explained historical plan of nature. His conception of nature is both man-centered and teleological. For him not the moderate realisation of selfinterest, namely competition, but life-and-death struggle, survival of the fittest, is the mechanism of progress. And equilibrium is not a perpetually reappearing (and redisturbed) state, but the final phase of history, the 'new Jerusalem', where conflict is replaced by non-destructive, yet stimulating, competition. This state of eternal peace is the final realisation of the progress of the human species towards the full development of all its natural talents, of which the summit is an autonomous, rational, moral order.

To focus our comparison on the conceptual coherence studied in this article: Smith's conception of reason has discernment of utility/agreeability at its core; Kant identifies the ability to choose and evaluate as its axis. For both of them, rationality is the highest form of human action, but they agree that, depending on the level of development other modes of action may be dominant. For both Smith and Kant survival (de- 
fending one's own dearest interests) - and whatever precautions may be taken for its sake - is a mechanism of progress. Rationality may be part of it, but decisive is the supra-individual teleology of nature. Balance, either as norm or as mechanistic equilibrium, is present in both thinkers and is presented as the aim of nature. Progress is the overall tendency in both Smith and Kant. (These concepts do appear also in Hume, but the way in which they are interrelated is somewhat different, probably because the Neo-Classicist aspect of his thought is more strongly developed, and because of his adherence to an Aristotelian, structural, view of the mind (Venter, 1992?)).

It was assumed at the beginning that contemporary culture has some roots in this eighteenth century combination of

* a teleological rationality, with

- the motive of conflict/competition (self-preservation) which is supposed to produce quality, and

- the belief in economic/material progress as a basis for human ('spiritual') advancement;

* the striving for growth and expansion ('bigger', 'better') without limits.

There are easily traceable links from Rousseau and Hume to Kant and Adam Smith, and from the latter to Malthus, Ricardo, Marx, Darwin, Spencer and Freud. Social Darwinism has had a stronghold in economic practice (and was even combined with Protestantism in the thought of W. G. Sumner). The Pragmatists have been 'teaching' us that ideas that work, i. e. improve the situation or help us survive, have truth-value, and Sir Karl Popper's falsificationism is nothing but a survivalist theory of science. Strictly competition-based social theories (for example those of Milton Friedman or F. A. von Hayek) are clearly part of this continuous tradition. We know that some of these theories have become everyday practice, and parts of some are cultivated into lifestyles by the boulevard press. The cult of 'stars' (whether football or Hollywood 'stars'), the 'publish or perish' style which the academic enterprise has assumed, the cult of success in schools (and the quiet rejection of 'mediocrity' or the 'drop-out'), the ridiculous and/or adsurdly dangerous attempts at making it into the Guinness Book of Records - are they not possibly the products of the analysed coherence of concepts in the eighteenth century life-view? (And didn't the counter culture, the student revolt of 
'68, the constant reappearance of fringe groups, indicate that for some the cult of competition was becoming unbearable?)

This cluster of established (practised) ideas have not gone unchallenged. Note the rejection of the modern world view of quantitative 'giantification' by Heidegger (1938; 1959), the penetrating criticism of rationality as self-preservation by Horkheimer (1978, 47-48); the shock waves that, for example, Mussolini's practical interpretation of the ennobling function of conflict sent through the Western world (the continuous abhorrence of 'fascism'), and the resistance of socialists (from Godwin and Owen in the nineteenth century, through the New Left right up to present-day social democrats), the ' 68 student revolutionaries, and the contemporary New Agers (cf. Capra, 1984) against an all too competitive and success-oriented society; the criticism of unlimited growth from different sources (Goudzwaard, 1978; Capra, 1984: $194 \mathrm{ff}$ ); the challenges to Marxism's adoption of the base-superstructure model, which is, for example, absent from the Marxist reading of the Bible by Gardavsky (1970).

It was stated, during the analysis of the eighteenth century, that the Enlightenment represents a final break with the synthetic life-view which flourished during the Middle Ages. It amounted to the rejection of the remnants of Christianity in the synthetic lifeview, and a replacement of these with especially the cluster of concepts analysed above. We can see something of this break in Voltaire's attacks on the Catholic church, Rousseau's rejection of Christianity as a candidate for his civil religion (specifically because Christ teaches love of the enemy), Adam Smith's attempt to deny bencvolence any essential role in the establishment of society and his explicit predilection for a purely Classical morality. The details of this break could not be analysed, but clearly some of the Enlightenment ideas were inconsistent with some originally Christian (biblical) basic ideas. Self-preservation and self-interest remains inconsistent with the biblical idea of love (cf. for example Matt. 5:38-47; Romans 12:921); progress brought about by man's own efforts under the guidance of nature is clearly in conflict with the biblical idea of history as the way in which the sovereign God guides his faithful (part of a depraved and degenerate mankind), to final salvation (Hebrews 12; Revelations 19-22); benevolence, support for the needy, sharing of burdens - these are some of the biblical ways in which the meaning of work is disclosed (cf. for example 2 Cor. 8:1-15; Galatians 6:1-9; 1 Tim. 6:3-21; James 5:1-6); both Smith and Kant believe that the well-being of all mankind depends on exactly the opposite: stimulation of ego-centrism and controlled conflict-labour is only made meaningful by gain and victory. If this is true, then the cluster of concepts analysed above also spells the maturation of secularism in the West. 


\section{BIBLIOGRAPHY}

CAPRA, F. 1984. The Turning Point; Science, Society, and the Rising Culturc. London : Fontana

FOUCAULT, M. 1986. The Foucault Reader. Ed. by Rabinow, P. Harmondsworth : Penguin Books.

GARDAVSKY, V. 1970. Nog is God niet dood; Een marxist over bijbel, christendom en athe isme Baarn : Bosch \& Keuning.

GOUDZWAARD, B. 1978. Kapitalisme en vooruitgang. Assen : Van Gorcum.

HEIDEGGER, M. 1938. Die Zeit des Weltbildes. (In Holzwege, Frankfurt a. M.: Klostermann. p. 69 104.)

HEIDEGGER, M. 1959. Unterwegs zur Sprache. Pfullingen : Neske

HORKHEIMER, M. 1978. The End of Reason. (In Arato, A. \& Gebhardt, E. eds., The Essential Frankfurt School Reader. Oxford : Blackwell. p. 26-48.)

KANT, 1. 1783. Beantwortung der Frage: Was ist Aufklärung. (In Weischedel, W., hrsg. 1975. Werke in Zehn Bänden. Bd 9. p. 33-50.)

KANT, I. 1784. Idec zu Einer Allgemene Geschichte in Weltburgerliche Absicht. (In Weischedel, W., hrsg. 1975. Werke in Zehn Banden. Bd 9. p. 33-50.)

KANT, I. 1786. Mutmasslicher Anfang der Menschengeschichte. (In Weischedel, W., hrsg., 1975. Werke in Zehn Bänden. Bd 9. p. 85-102.)

KANT, I. 1795. Zum Ewigen Frieden. (In Weischedel, W., hrsg., 1975. Werke in Zehn Bänden. Bd 9 p. 195-251.)

MACHLAVELLI, N. 1979. The Discourses. Harmondsworth : Penguin Books.

MANENSCHIJN, G. 1979. Moraal en eigenbelang bij Thomas Hobbes en Adam Smith. Amsterdam : Rodopi.

MUSSOLINI, B. 1935. Fascism: Doctrines and Institutions. Rome : Ardita.

RAPHAEL, D. D. 1975. The Impartial Speclator. (In Skinner, A.S. \& Wilson, T. eds., Essays on Adam Smith. Oxford: Clarendon. p. 93-101.)

SMITH, A. 1759. The Theory of Moral Sentiments. (In The Glasgow Edition of the Works and Correspondence of Adam Smith. Oxford : Clarendon. 1976.)

SMITH, A. 1776. An Inquiry into the Nature and Causes of the Wealth of the Nations (Ed. E. Cannan.) London: Methuen. 1950.

SMITH, A. 1980. Essays on Philosophical Subjects. (Ed. Wightman, W.D.P. \& Bryce, J.C.) Oxford Clarendon.

SMITH, A. 1980. The Principles which Lead and Direct Philosophical Enquiries Illustrated by the History of Astronomy. (In Wightman, W.P.D. \& Bryce, J.C. eds. Adam Smith, Essays on Philosophical Subjects. Oxford: Clarendon. p. 33-105.)

VENTER, J.J. 1992?. Ontologie, representasie en metode. (In Viljocn, H.M. red., Die Representasieprobleem. Manuscript of a research report to be published by the Human Science Research Council, Pretoria, probably during 1992. p. 116-199.) 